\title{
Antimicrobial Susceptibility of Clostridium difficile Clinical Isolates in Iran
}

\author{
Mehdi Goudarzi ${ }^{1,2}$, Hossein Goudarzi ${ }^{2}$, Masoud Alebouyeh ${ }^{1}$, Masoumeh Azimi Rad ${ }^{1}$, \\ Farahnaz Sadat Shayegan Mehr $^{1}$, Mohammad Reza Zali ${ }^{1}$, Mohammad Mehdi Aslani ${ }^{1,3,}$ \\ ${ }^{1}$ Research Center for Gastroenterology and Liver Diseases, Shahid Beheshti University of Medical Sciences, Tehran, IR Iran \\ 2 Department of Microbiology, Shahid Beheshti University of Medical Science, Tehran, IR Iran \\ 3 Department of Microbiology, Pasteur Institute, Tehran, IR Iran \\ *Corresponding author: Mohammad Mehdi Aslani, Department of Microbiology, Pasture Institute, Tehran, IR Iran. Tel: +98-2166405535, Fax: +98-2166465132, E-mail: mmaslani@
} yahoo.com.

Received: April 14, 2012; Revised: January 20, 2013; Accepted: Jun 14, 2013

Background: Clostridium difficile infection(CDI) is major growing problem in hospitals and its high incidence has been reported in recent years.

Objectives: The aim of this study was to investigate the antimicrobial susceptibility patterns of $C$. difficile clinical isolates againstantibiotics commonly used for treatment CDI in hospitalized patients.

Material and Methods: During a 12 month study, 75 C. difficile isolates were collected from 390 patients with CDI. All samples were treated with alcohol and yeast extract broth. The treated suspensions were cultured on a selective cycloserine cefoxitin fructose agar (CCFA) supplemented with $5 \%$ sheep blood and incubated in anaerobic conditions, at $37^{\circ} \mathrm{C}$ for 5 days. Cdd-3, tcdA and tcdB genes were identified using PCR assay.

Results: The prevalence of $\mathrm{A}^{+} \mathrm{B}^{+}, \mathrm{A}^{+} \mathrm{B}^{-}$and $\mathrm{A}^{-} \mathrm{B}^{+}$strains were $64(85.3 \%), 5(6.7 \%)$ and $6(8 \%)$ respectively. In vitro susceptibility of 75 clinical isolates of $C$. difficile to 5 antimicrobial agents, including metronidazole, vancomycin, clindamycin, erythromycin and cefotaxime were investigated by Clinical and Laboratory Standards Institute (CLSI) agar dilution method. Metronidazole and vancomycin had good activity against C. difficile isolates with MIC90s of 2 and $1 \mu \mathrm{g} / \mathrm{ml}$, respectively. Seventy one (94.6\%) of strains was inhibited by concentrations that did not exceed $2 \mu \mathrm{g} / \mathrm{ml}$ for metronidazole. Resistant to metronidazole observed in 5.3\% of isolates. Forty three (57.3\%) of the isolates were resistant to erythromycin. Of 43 resistant strains to erythromycin, 9 (12\%) isolates had high-level MIC of more than $64 \mu \mathrm{g} / \mathrm{ml}$. All strains were resistant to cefotaxime. Sixty seven (89.3\%) isolates were resistant to clindamycin (MIC90s $>256 \mu \mathrm{g} / \mathrm{ml}$ ) and only $6.7 \%$ were sensitive to clindamycin. Multidrug-resistant (three or more antibiotics) was seen in 36(48\%) isolates.

Conclusions: Metronidazole and vancomycin still seem to be most effective drugs for treatment CDI.

Keywords: Clostridium Difficile; Antibiotic Resistance; Clindamycin

\section{Background}

Clostridium difficile is gram-positive rod, spore forming, strict anaerobic bacillus and the major cause of nosocomial diarrhea (1). C. difficile is responsible for a spectrum of $C$. difficile infection (CDI) that can be ranged from mild, self-limiting diarrhoea to a severe colitis, pseudomembranous colitis or toxic megacolon (2). Toxins A and B from C. difficile are major factors which initiate the creation of CDI. Both of the toxins induce mucosal injury and colitis (3). CDI appears as a major complication of antibiotic therapy and is linked with hospital admission. Exposure to almost all classes of antibiotics has been associated with CDI $(4,5)$. In healthy persons, the growth of this bacterium is controlled by the intestinal normal flora. The use of broad-spectrum antimicrobials may cause depletion of the patient's normal protective bowel microbiota and promote proliferation of toxigenic $C$. difficile. Therefore Antimicrobial therapy plays a central role in the development of $\mathrm{CDI}(4,6)$.

Metronidazole and vancomycin are the first choice drugs for treatment of CDI but there is a high incidence of relapses (7). Several studies have proven that these two antibiotics are the mainstays for the treatment of mild to moderate disease $(7,8)$. Decreased susceptibility and increased resistance to metronidazole has caused to change standard antimicrobial therapy for CDI (9). Teicoplanin as a one of glycopeptide antibiotics have as equally effective as metronidazole and should be reserved for patients who cannot tolerate metronidazole (10). The effective treatment of $\mathrm{CDI}$ is considerably challenged with the emergence of new multi-drug resistant epidemic strains of these bacteria (11). In clinical laboratories, because of 
the need for anaerobic facility, expert technician and cost, antibiotic susceptibility testing is not routinely performed for $C$. difficile. Although in the most of studies susceptibility of $C$. difficile to metronidazole and vancomycin has been reported but recent studies described increase resistant and reduced sensitivity to metronidazole and vancomycin $(12,13)$. Information about CDI and also antimicrobial resistance profiles of $C$. difficile isolates in Iran is very sparse, but reports from Europe and North America indicates that prevalence of infections caused by C. difficile and resistance against antibiotics commonly used for treatment of this bacteria is increasing rapidly (14).

\section{Objectives}

The aim of this study was to investigate the antimicrobial susceptibility patterns of C.difficile clinical isolates against antibiotics commonly used for treatment CDI in hospitalized patients.

\section{Material and Methods}

\subsection{Bacterial Isolates}

A total of 75 clinical isolates of $C$. difficile were recovered from the 350 stool specimens of patients with CDI who were referred to the Research center for Gastroenterology and Liver Disease (RCGLD) as a referral laboratory during November 2010 to Oct 2011 were included in this study. A questionnaires containing different clinical and personal data i.e. clinical symptoms, antibiotic usages and underlying conditions was completed for all person. Diarrhea was defined as the passage more than 3 loose or watery stools during a 24-h period (15).

All the stool samples were transported to the laboratory and were processed immediately. Stool specimens were treated with alcohol and yeast extract broth. For alcohol treatment about $1 \mathrm{~g}$ of stool was mixed with an equal volume of $95 \%$ ethanol, slowly vortex and held at room temperature for $2 \mathrm{~min}(16)$. The treated suspensions were cultured on cycloserine- cefoxitin fructose agar (CCFA,) supplemented with $5 \%$ sheep blood for isolation of $C$. difficile. For yeast treatment, about $1 \mathrm{~g}$ of stool was mixed with an equal volume of yeast extract broth (Yeast extract granulated; Merck, Germany) and then treated suspensions were cultured on CCFA supplemented with $5 \%$ sheep blood. Plates were incubated in anaerobic conditions (Anoxomat: MART Microbiology B.V. the Netherlands, $0 \% \mathrm{O} 2,10 \% \mathrm{H} 2,10 \% \mathrm{CO} 2,80 \% \mathrm{~N} 2)$ at $37^{\circ} \mathrm{C}$ for 48 h. All plates were monitored daily up to 5days. Negative cultures were maintained in incubator up to 7 days. $C$. difficile isolates were presumptively identified by characteristic morphology of colony, specific horse-stable odor, Gram stain, green- chartreuse fluorescence under a ultraviolet (UV) light. Samples confirmed as a C. difficile were stored in cooked meat broth (Cooked Meat Medium: Himedia) at $4^{\circ} \mathrm{C}$ and were subjected to further molecular identification.

\subsection{DNA Extraction and PCR of Toxigenic Genes}

DNA was extracted from bacteria on CCFA medium by Using QIAamp DNA isolation columns (Qiagen, Hilden, Germany) according to the manufacturer's procedure. The presence of PaLoc accessory gene cdd-3 was detected by PCR as described previously by Cohen et al. ( 17 ). All C.difficile isolates were subjected for the determination of toxin genes. The detection of Toxin A gene (tcdA) and toxin $B$ gene (tcdB) was performed by the methods described by Cohen et al.( 17 ) Primer sequences used for detection of cdd-3, tcdA and tcdB genes and their fragment size are presented in Table 1 . The PCR reactions for detection tcdA and tcdB genes were done a total volume of $25 \mu \mathrm{L}$ The reaction mixture contained $1 \mathrm{x}$ buffer $(10 \mathrm{mM}$ Tris-HCl, $50 \mathrm{mM} \mathrm{KCl}$ ), $1.5 \mathrm{mM} \mathrm{MgCl} 2,0.2 \mu \mathrm{M}$ of each deoxynucleoside triphosphate, $0.5 \mu \mathrm{M}$ of TA1 and TA2 primers, $0.5 \mu \mathrm{M}$ of TB1 and TB2 primers, and $1.5 \mathrm{U}$ of Takara Taq (Takara Shuzo Co., Ltd., Shiga, Japan).

Table 1. Primers Sequence Used for Amplification cdd3, tcdB and tcdA Genes

\begin{tabular}{|c|c|c|c|}
\hline Gene & Primer & Nucleotide sequence & Fragment Length (bp) \\
\hline \multirow[t]{2}{*}{ Cdd-3 } & Tim6 & $5^{-}$TCC AAT ATA ATA AAT TAG CAT TCC A $3^{-}$ & 622 \\
\hline & Struppi6 & $5^{\prime}$ GGC TAT TAC ACG TAA TCC AGA TA $3^{-}$ & \\
\hline \multirow[t]{2}{*}{ TcdA } & TA1 & $5^{\prime}$ ATG ATA AGG CAA CTT CAG TGG $3^{-}$ & 624 \\
\hline & TA2 & $5^{`}$ TAA GTT CCT CCT GCT CCA TCA A $3^{\prime}$ & \\
\hline \multirow[t]{2}{*}{ TcdB } & TB1 & $5^{`}$ GAG CTG CTT CAA TTG GAG AGA $3^{-}$ & 412 \\
\hline & TB2 & $5^{\circ}$ GTA ACC TAC TTT CAT AAC ACC AG $3^{-}$ & \\
\hline
\end{tabular}

PCR conditions for amplification of 624 bp fragment of the tcdA gene was done by thermocycler (AG 22331; Eppendorf, Hamburg, Germany) as follows: initial denaturation at 5 min at $95^{\circ} \mathrm{C}$, followed by 35 cycles of $1 \mathrm{~min}$ at $95^{\circ} \mathrm{C}, 1 \mathrm{~min}$ at $58^{\circ} \mathrm{C}$, and $1.5 \mathrm{~min}$ at $72{ }^{\circ} \mathrm{C}$; and final extension at $72{ }^{\circ} \mathrm{C}$ for $10 \mathrm{~min}$ to end amplification process. For amplification of $412 \mathrm{bp}$ fragment of the tcdB gene the following time-temperature profile was used: $5 \mathrm{~min}$ at 
$94^{\circ} \mathrm{C}$ for initial denaturation, 35 cycles of $1 \mathrm{~min}$ at $94^{\circ} \mathrm{C}, 1$ min at $51^{\circ} \mathrm{C}$, and 80 s at $72{ }^{\circ} \mathrm{C}$; and a final extension cycle of $5 \mathrm{~min}$ at $72{ }^{\circ} \mathrm{C}$. Amplified fragments were separated by $1.2 \%$ agarose gel electrophoresis at $80 \mathrm{~V}$ for $2 \mathrm{~h}$. Finally, fragments were stained by ethidium bromide and detected under UV light.

\subsection{Minimum Inhibitory Concentration (MIC)}

The antimicrobial susceptibility profile for all isolates was determined by estimating MIC of the 5 antibiotics using agar dilution method according Clinical Laboratory and Standards Institute (CLSI; formerly National Committee for Clinical Laboratory Standards) criteria for anaerobes (M11-A6) (18). The MIC was defined as the lowest concentration of each antimicrobial agent that inhibited visible growth of the tested isolate. The following antimicrobial agents were used in this study: metronidazole, vancomycin, cefotaxime, clindamycin, erythromycin (Sigma-Aldrich, St. Louis, Mo). The ranges of MIC value used for antimicrobial agents were including: metronidazole 0.125 to $32 \mu \mathrm{g} / \mathrm{ml}$; vancomycin 0.25 to $16 \mu \mathrm{g} / \mathrm{ml}$; cefotaxime 4 to $512 \mu \mathrm{g} / \mathrm{ml}$; clindamycin 0.5 to 256 and erythromycin 0.5 to $32 \mu \mathrm{g} / \mathrm{ml}$. In brief, serial twofold dilutions of antibiotics were incorporate in to enriched Brucella agar (Oxide supplemented with 5\% defibrinated sheep blood, $5 \mu \mathrm{g} / \mathrm{ml}$ haemin and $\mu \mathrm{g} / \mathrm{ml}$ vitamin K1) for determination of antibiotic susceptibility. The stock solutions of each drug were prepared in accordance with manufacturer's instructions and kept at $-20^{\circ} \mathrm{C}$. From these stock solutions, working solutions were made in distilled water to be incorporated into the Brucella blood agar media. Media with different concentrations of each antibiotic were prepared by adding defined amount of each antibiotic to cooled Brucella agar media. The bacterial suspension obtained from overnight cultures. The turbidity of each bacterial suspension was adjusted equivalent to a no. 1.0 McFarland standard and $20 \mu \mathrm{l}$ of them were inoculated on Brucella agar plates containing different concentrations of each antibiotic and plates without antibiotics as control. Control plates were included with each test run of susceptibility testing. Antibiotic resistance was defined as follows: MIC $\geq 32 \mu \mathrm{g} / \mathrm{ml}$ for metronidazole, MIC $\geq 64$ $\mu \mathrm{g} / \mathrm{ml}$ for cefotaxime, MIC $\geq 8 \mu \mathrm{g} / \mathrm{ml}$ for clindamycin, MIC $\geq 8 \mathrm{mg} / \mathrm{L}$ for erythromycin according to the Clinical and Laboratory Standard Institute (CLSI) recommendations (18).

\section{Results}

Clinical features of 75 patients with CDI are given in Table 2. The patients were distributed in 7 hospital department. All patients hospitalized in gastroenterology ward had history of previous surgery and use of proton pomp inhibitors. The most common underlying disease was renal failure, infectious disease and cancer. Ninety two percent of patients had antibiotic therapy. Over 50\% of them were treated with the Beta-lactam antibiotic. Only 6 patients ( $8 \%$ ) did not receive a specific treatment. The toxin profiles $\mathrm{A}^{+} \mathrm{B}^{+}, \mathrm{A}^{+} \mathrm{B}^{-}$and $\mathrm{A}^{-} \mathrm{B}^{+}$accounted for $64(85.3 \%), 5(6.7 \%)$ and $6(8 \%)$ of studied strains respectively. PCR products of the tcdA and tcdB genes are shown in Figure 1. All patients hospitalized in ICU and oncology ward were $\left(\mathrm{A}^{+} \mathrm{B}^{+}\right)$and had history of usage of antibiotics such as beta lactams, aminoglycosides and flouroquinolones. A total of $6\left(\mathrm{~A}^{-} / \mathrm{B}^{+}\right)$strains were isolated from different wards including 3 from ICU, 2 from infectious and 1 from oncology ward. All patients with profile $\mathrm{A}^{-} / \mathrm{B}^{+}$had underlying morbidity, leucosytisis and history of previous use of cephalosporines, aminoglycosides and Beta-lactams antibiotics. Surprisingly, 5 strains were toxin A positive but toxin B negative. They were isolated from patients with fever, abdominal pain and previous use of antibiotics.

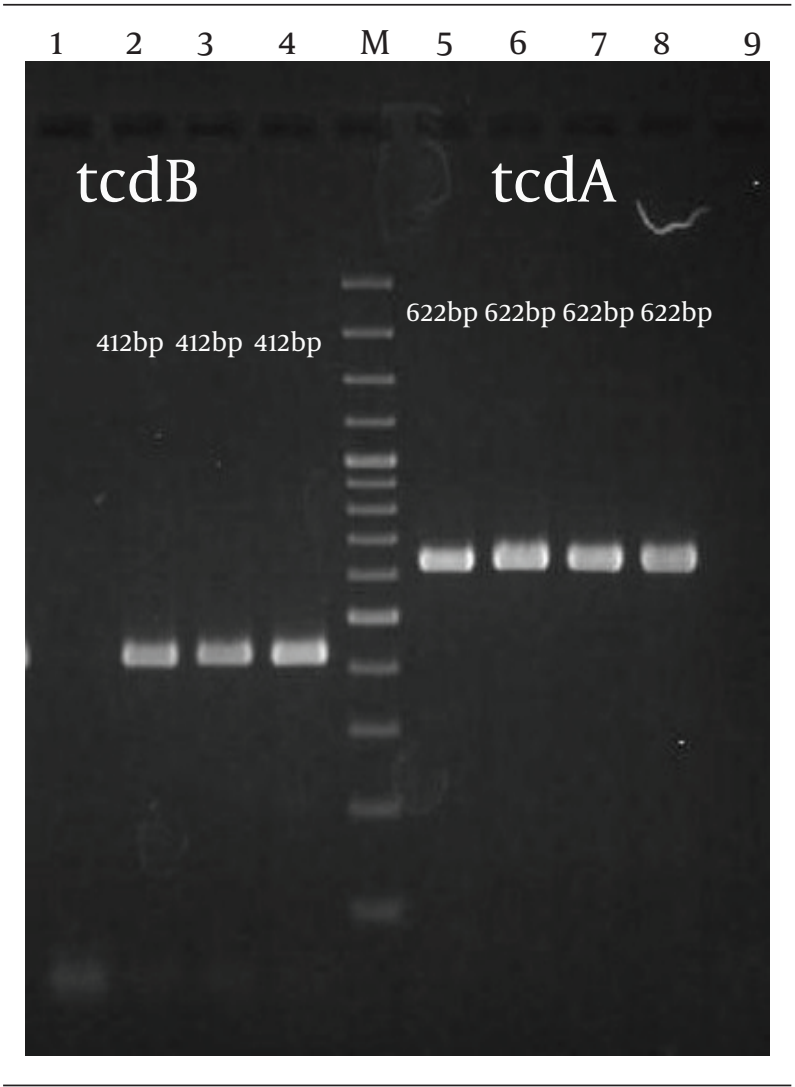

Figure 1. Detection of tcdA and tcdB genes by PCR.lane 1 negative control of tcdB gene, lan2 and 3 PCR tcdB gene,lan 4 control positive of tcdB gene, lane 5,6 and 7 PCR tcdA gene, lane 8 control positive of tcdA gene, lane 9 negative control of tcdA gene, lane M, DNA ladder, $100 \mathrm{bp}$ 
Table2. Demographic and Epidemiological Characteristics of 75 Patients with CDI

\begin{tabular}{|c|c|}
\hline Characteristic & No. $(\%)$ \\
\hline \multicolumn{2}{|l|}{ Gender } \\
\hline Male & $39(52)$ \\
\hline Female & $36(48)$ \\
\hline \multicolumn{2}{|l|}{ Age, years } \\
\hline$\leq 50$ & $41(54.6)$ \\
\hline $51-65$ & $11(14.7)$ \\
\hline$>65$ & $23(30.7)$ \\
\hline \multicolumn{2}{|l|}{ Laboratory parameters } \\
\hline Nuetropenia & $7(9.3)$ \\
\hline Leucocytosis & $19(25.3)$ \\
\hline blood in stool & $12(16)$ \\
\hline \multicolumn{2}{|l|}{ Clinical parameters } \\
\hline Fever & $36(48)$ \\
\hline Abdominal pain & $51(68)$ \\
\hline $\begin{array}{l}\text { Duration of diarrhea(more } \\
\text { than twice per day: days) }\end{array}$ & $4.9 \pm 5.8$ \\
\hline $\begin{array}{l}\text { Duration of hospitaliza- } \\
\text { tion }\end{array}$ & 10.5 \\
\hline Abdominal surgery & $35(46.6)$ \\
\hline Previous surgery & $17(22.7)$ \\
\hline Previous hospitalization & $38(50.7)$ \\
\hline $\begin{array}{l}\text { Use of immunosuppressive } \\
\text { drugs }\end{array}$ & $12(16)$ \\
\hline $\begin{array}{l}\text { Use of protone pump } \\
\text { inhibitors }\end{array}$ & $19(25.3)$ \\
\hline Nasogastric tube & $10(13.3)$ \\
\hline Chemotherapy & $2(2.7)$ \\
\hline \multicolumn{2}{|l|}{ Diagnosis on admission } \\
\hline $\begin{array}{l}\text { Hematological malignan- } \\
\text { cies }\end{array}$ & $5(6.7)$ \\
\hline Cancer & $7(9.3)$ \\
\hline Renal failure & $11(14.6)$ \\
\hline Infectious disease & $5(6.7)$ \\
\hline Chronic disease & $4(5.3)$ \\
\hline others & $43(57.3)$ \\
\hline \multicolumn{2}{|l|}{ Hospital ward } \\
\hline Internal medicine & $20(26.7)$ \\
\hline Intensive care unit & $15(20)$ \\
\hline Infectious ward & $14(18.7)$ \\
\hline Surgical ward & $10(13.3)$ \\
\hline Oncology & $10(13.3)$ \\
\hline Gastroenterology & $4(5.3)$ \\
\hline Pediatric & $2(2.7)$ \\
\hline \multicolumn{2}{|l|}{ Previous use of antibiotics } \\
\hline Penicillin & $47(62.6)$ \\
\hline cephalosporin & $41(54.6)$ \\
\hline clindamycin, & $21(28)$ \\
\hline aminoglycoside & $14(18.6)$ \\
\hline fluoroquinolone & $11(14.6)$ \\
\hline metronidazole & $8(10.6)$ \\
\hline vancomycin & $4(5.3)$ \\
\hline other & $15(20)$ \\
\hline
\end{tabular}

In vitro susceptibility of the $C$. difficile isolates to 5 antibiotics tested and the range of Minimum Inhibitory Concentration required to inhibit the growth of 50\% of organisms (MIC 50 ) and Minimum Inhibitory Concentration required to inhibit the growth of $90 \%$ of organisms (MIC 90 ) are summarized in Table 3. All isolates were resistant to cefotaxime. Of all the isolates resistant to cefotaxime , 27 (36\%) of isolates had MIC $\geq 64 \mu \mathrm{g} / \mathrm{ml}, 40$ (53.3\%) had MIC $\geq 128 \mu \mathrm{g} / \mathrm{ml}, 5$ (6.7\%) had MIC $\geq 256 \mu \mathrm{g} / \mathrm{ml}$ and 3(4\%) had MIC $\geq 512 \mu \mathrm{g} / \mathrm{ml}$. Increased resistance to metronidazole was observed for 4 (5.3\%) of isolates (three strains for which the MICs were $32 \mu \mathrm{g} / \mathrm{ml}$, the remaining one strain for which the MIC was $64 \mu \mathrm{g} / \mathrm{ml})$. The MIC values of metronidazole for remaining 71(94.7\%) of isolates was ranged from 0.125 to $2 \mu \mathrm{g} / \mathrm{ml}$.

The results of metronidazole MIC were as fallow: 5 (6.7\%) of isolates had MIC $0.125 \mu \mathrm{g} / \mathrm{ml}, 14(18.7 \%)$ had MIC $0.25 \mu \mathrm{g} /$ $\mathrm{ml}, 37$ (49.3\%) had MIC $0.5 \mu \mathrm{g} / \mathrm{ml}, 12$ (16\%) had MIC $1 \mu \mathrm{g} / \mathrm{ml}$, 3 (4\%) had MIC $2 \mu \mathrm{g} / \mathrm{ml}, 3$ (4\%) had MIC $32 \mu \mathrm{g} / \mathrm{ml}$ and 1(1.3\%) had MIC $64 \mu \mathrm{g} / \mathrm{ml}$. There was any intermediate isolate for metronidazole. Among metronidazole resistant isolates, one strain with MIC $\geq 64 \mu \mathrm{g} / \mathrm{ml}$ was isolated from a 66-years-old HIV positive patient who had undergone gastrointestinal disease. The other patient infected by metronidazole resistant strain was a child with malignancy who had been received metronidazole treatment. As it was shown, $43(57.3 \%)$ and $67(89.3 \%)$ of the isolates were resistant to erythromycin and clindamycin respectively. Out of 43 resistance isolates to erythromycin, 13 (17.3\%) of isolates had MIC $\geq 8 \mu \mathrm{g} / \mathrm{ml}, 12(16 \%)$ had MIC $\geq 16 \mu \mathrm{g} / \mathrm{ml}, 9$ (12\%) had MIC $\geq 32 \mu \mathrm{g} / \mathrm{ml}$ and $9(12 \%)$ exhibited MIC $\geq 64 \mu \mathrm{g} / \mathrm{ml}$. Nine (12\%) of isolates were intermediate to erythromycin. From 67 resistance isolates to Clindamycin, 7 ( 9.3\% ) of isolates had MIC $\geq 8 \mu \mathrm{g} / \mathrm{ml}, 10$ (13.3\%) had MIC $\geq 16 \mu \mathrm{g} / \mathrm{ml}, 13$ ( 17.3\%) had MIC $\geq 32 \mu \mathrm{g} / \mathrm{ml}, 29$ (38.6\%) had MIC $\geq 128 \mu \mathrm{g} / \mathrm{ml}$ and $8(10.6 \%)$ had MIC $\geq 256 \mu \mathrm{g} / \mathrm{ml}$. Just 3(4\%) of all isolates were intermediate to clindamycin.

All of $C$. difficile strains except six of them were inhibited by vancomycin at MIC $\leq 2 \mu \mathrm{g} / \mathrm{ml}$. Out of 6 resistance isolates to vancomycin, 4(66.7\%) of isolates had MIC $2 \mu \mathrm{g} / \mathrm{ml}$ and 2 (33.3\%) had MIC $4 \mu \mathrm{g} / \mathrm{ml}$. Two isolates with high value MIC to vancomycin (MIC $4 \mu \mathrm{g} / \mathrm{ml}$ ) were positive for both toxin $\mathrm{A}$ and $\mathrm{B}\left(\mathrm{A}^{+} \mathrm{B}^{+}\right)$and recovered from the same hospital. The MIC90s of clindamycin and cefotaxim were alike $(256 \mu \mathrm{g} / \mathrm{ml})$. All of $C$. difficile strains were inhibited by vancomycin at similar MIC50 and MIC90 $1 \mu \mathrm{g} / \mathrm{ml}$. In this study metronidazole and vancomycin showed good in vitro activity against all strain tested, with MIC90 of 1 and $2 \mu \mathrm{g} / \mathrm{ml}$ respectively. According to our results highest (100\%) and lowest (5.3\%) levels of resistance were related to cefotaxim and metronidazole respectively.

Multidrug-resistant (MDR) was defined as resistance to at least three or more antibiotics.15 Of 75 isolates tested $36(48 \%)$ were MDR. In particular, thirty nine (52\%) of isolates were resistant to at least two drugs, Thirty one (41.3\%) of isolates were resistant to at least three drugs and 5(6.7\%) 
Goudarzi M et al.

\begin{tabular}{|c|c|c|c|c|c|c|c|}
\hline \multirow[t]{2}{*}{ agent } & \multicolumn{3}{|c|}{$\operatorname{MIC}(\mu \mathrm{g} / \mathbf{m l})$} & \multicolumn{3}{|c|}{ No.(\%)of isolates } & \multirow[t]{2}{*}{ MICI nterpretive Breakpoints $(S / I / R)^{\mathrm{a}}(\mathrm{S} / \mathrm{I} / \mathrm{R})$} \\
\hline & Range & $50 \%$ & $\mathbf{9 0} \%$ & $S$ & $\mathbf{I}$ & $\mathbf{R}$ & \\
\hline Metronidazole & $0.125-32$ & 0.5 & 2 & $71(94.7)$ & $0(0)$ & $4(5.3)$ & $\leq 8 / 16 / 32 \geq$ \\
\hline Vancomycin $^{\mathrm{b}}$ & $0.25-16$ & 1 & 1 & 92 & $0(0)$ & $6(8)$ & $\geq 2$ \\
\hline Cefotaxime & $4-512$ & $>128$ & 256 & $0(0)$ & $0(0)$ & $75(100)$ & $\leq 16 / 32 / 64 \geq$ \\
\hline Clindamycin & $0.5-256$ & 32 & 256 & $5(6.7)$ & $3(4)$ & $67(89.3)$ & $\leq 2 / 4 / 8 \geq$ \\
\hline Erythromycin & $0.5-32$ & 4 & $>32$ & $23(30.7)$ & $9(12)$ & $43(57.3)$ & $\leq 2 / 4 / 8 \geq$ \\
\hline
\end{tabular}

a MIC breakpoints applied were those recommended for anaerobes by the Clinical and Laboratory Standards Institute (CLSI)

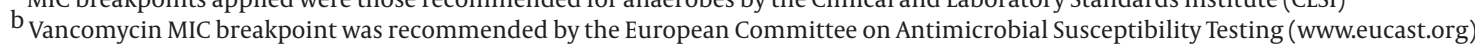

of the isolates were resistant to four drugs. Frequencies of resistance to two or more antibiotics are summarized in Table 4. MDR strains to three or more tested antibiotics were isolates from hospitalized patients in ICU, internal medicine, infectious, oncology and gastroenterology wards respectively. The predominant resistance profile among our isolates were included resistance to 2 antibiotices (cefotaxim, clindamycin) and 3 antibiotices (cefotaxim, clindamycin, erythromycin), which were common among 31(41.3\%) and 30 (40\%) isolates.

Table 4. Distribution of Antibiotic Resistance Profile AmongC. difficileStrains

\begin{tabular}{lllll}
\hline Resistance group & Toxin A positive & Toxin B positive & Toxin A and B positive & Total, No. \\
\hline CEF,CLI,ERY,MTZ & - & 1 & 2 & 3 \\
CEF,CLI,ERY,VAN & - & - & 2 & 2 \\
CEF,CLI,ERY & 3 & 2 & - & 30 \\
\hline CEF,CLI,VAN & 1 & - & 27 & 31 \\
CEF,CLI & 1 & 3 & 7 & 7 \\
CEF,ERY & - & - & 1 & 1
\end{tabular}

\section{Discussion}

CDI is a potentially fatal illness with an increasing incidence worldwide and responsible for $10-20 \%$ cases of antibiotic-associated diarrhea (AAD) and almost all cases of colitis associated with antibiotic therapy $(6,19,20)$. In this study we studied susceptibility pattern of the 75 clinical isolates of $C$. difficile to 5 different antibiotics as common therapeutic drugs in hospitalized patients. Of the total 75 isolates, 6 ( $8 \%$ ) were $\mathrm{A}^{-} \mathrm{B}^{+}$strains. Several investigators believe that $\mathrm{CDI}$ caused by $\mathrm{A}^{-} \mathrm{B}+$ strains is increasing (21). The prevalence of $\mathrm{A}^{-} \mathrm{B}^{+}$strains varies depending on geographic region and country studied. In Europe, 6.2\% of $C$. difficile isolates were $\mathrm{A}^{-} \mathrm{B}^{+}$variant (22). In a study conducted in Canada the prevalence of $\mathrm{A}^{-} \mathrm{B}^{+}$strains was $2.3 \%$ (23). In Shanghai $33.3 \%$ of the isolated strains were $\mathrm{A}^{-} \mathrm{B}^{+}$strains while in Stockholm did not identify any $\mathrm{A}^{-} \mathrm{B}^{+}$ strain (24). In Korea, $\mathrm{A}^{-} \mathrm{B}^{+}$variant was $25.7 \%$ of $C$. difficile isolates in 2010 (25). The prevalence of $\mathrm{A}^{-} \mathrm{B}^{+}$strains in Iran was much lower than Korea and Shanghai.

The MIC values for metronidazole have been reported differently by several researchers. In 2002, the MIC50 and MIC90 of metronidazole at 50\% of isolates tested were 0.5 and $4 \mu \mathrm{g} / \mathrm{ml}$, respectively in Spain (26). Lamothe et al. showed that all strains were susceptible to metronidazole and inhibited by MIC50 and MIC90 that did not exceed $0.25 \mu \mathrm{g} / \mathrm{ml}$ and $0.5 \mu \mathrm{g} / \mathrm{ml}$ respectively (27). In a study conducted in Sweden, the MIC of metronidazole for 238 C. difficile isolates ranged from 0.032 to $1 \mu \mathrm{g} / \mathrm{ml}$ (28). Poxton et al. showed that resistance to antibiotics during the three periods of the study has changed and also reported that the MIC50 and MIC90 values of metronidazole for 179 isolates were $0.5 \mu \mathrm{g} / \mathrm{ml}$ (29). In 2008 in the United Kingdom, the MIC50 and MIC90 results of the metronidazole in 677 clinical isolates of $C$. difficile were $0.38 \mu \mathrm{g} / \mathrm{ml}$ and $1.0 \mu \mathrm{g} /$ $\mathrm{ml}$ respectively (30). In a study done in Taiwan in 2011, Chien Ko et al. showed that all of strains were susceptible to metronidazole and the rate of MIC50 and MIC90 for metronidazole were $0.5 \mu \mathrm{g} / \mathrm{ml}$ and $1 \mu \mathrm{g} / \mathrm{ml}$ respectively (31).The data from present study showed that 71 (94.7\%) of isolates were inhibited by $2 \mu \mathrm{g} / \mathrm{ml}$ of metronidazole and only 4 (5.3\%) were resistance to metronidazole. Resistance to metronidazole in different countries is gradually increasing. Also isolates with decrease susceptibility to metronidazole has been confirmed by several investigators. Pelaez et al. reported the increased rate of resistant to metronidazole from $6.3 \%$ to $12 \%$ during three years ( 13 , 
26). Wong et al. showed that from 100 C. difficile isolates only single isolate was resistant to metronidazole and had MIC of $64 \mu \mathrm{g} / \mathrm{ml}$ (32).In compare to studies were performed in Taiwan (31), Canada (27), Sweden (24) and UK (30), a high resistance to metronidazole were seen in our study. This high resistance to metronidazole in Iran can be caused by indiscriminate use of metronidazole in the treatment of CDI and altered in the ability of bacteria to activate the drug (33). Although resistant to metronidazole is gradually increasing but it is still an effective drug for treatment C. difficile-associated diseases (34).

The data from our investigation show that $90 \%$ of isolates were inhibited by $1 \mu \mathrm{g} / \mathrm{ml}$ of vancomycin. Sixty nine (92\%) of isolates were inhibited by concentration that did not exceed $2 \mu \mathrm{g} / \mathrm{ml}$. Decreased susceptibility to vancomycin in C. difficile isolates has been reported previously(35). The study was conducted in 2004-2006 in Poland, has shown that all isolates were inhibited by concentrations that did not exceed $2 \mathrm{mg} / \mathrm{ml}$ for vancomycin (5). Another study that were done on United States, South America, and Europe isolates showed that all isolate except one were inhibited by vancomycin at a concentration of 2.0 $\mu \mathrm{g} / \mathrm{ml}(36)$. In Spain, decreased susceptibility to vancomycin reported in $10 \%$ of clinical strains of $C$. difficile (26). In another study that was conducted in Canada showed that all isolates were susceptible to vancomycin (27). Our finding about vancomycin is in accordance with recent data. Although decreased susceptibility to vancomycin among C. difficile isolates has been reported but it is still used as effective drug for CDI treatment.

All 75 isolates were resistant to cefotaxime with MIC90 more than $256 \mu \mathrm{g} / \mathrm{ml}$.This data is consistent with some earlier reports $(27,37)$. In 2005 , brazier et al. showed that all $271 \mathrm{C}$. difficile isolates were resistance to cefotaxim with MIC $\geq 64 \mu \mathrm{g} / \mathrm{ml}$ (38). In 2006, Lamothe et al. reported that all C. difficile isolates were resistance to cefotaxim with MIC50 and MIC90 $\geq 128 \mu \mathrm{g} / \mathrm{ml}$ (27). In another study conducted in Kuwait in 2002, all studied strains were resistance to cefotaxim with MIC50 and MIC90 96 and $\geq 256 \mu \mathrm{g} / \mathrm{ml}$ respectively (37). Resistance to cefotaxim among our isolates may be related to improper usage of this antibiotic for treatment of other infections, increase use of other beta lactam antibiotics in hospital and acquisition of resistant during hospitalization.

In spite of limitation in the use of clindamycin due to its association with the induction of $\mathrm{C}$. difficile diarrhea and a high risk of inducing CDI but resistant to clindamycin have been widely reported (39). The MIC of clindamycin for our isolates ranged from 0.5 to $256 \mu \mathrm{g} / \mathrm{ml}$. The clindamycin exhibited higher MIC than other antimicrobial agents tested with MIC90 of more than $256 \mu \mathrm{g} / \mathrm{ml}$ and had poor activity against the isolates. The resistance rate to clindamycin was $89.3 \%$ in our study, which was lower than Canada (90.9\%), but was higher than those in Korea (60\%), China (81.3\%), Kuwait (48\%), Sweden (65\%) and Taiwan $(46 \%)(23-25,31,37,40)$. The reason for resistance to clindamycin could be mediated resistance to other macrolide and also their widespread use in the hospital and the community.

The resistance rate to erythromycin was $57.3 \%$ in our study, which was lower than those in China (85.3\%), Scotland (94.8\%) and was higher than those in Germany (49 $\%)$, Hungary (25\%) and Sweden $(13.8 \%)(40,41)$. The possible reasons of high resistant rate to erythromycin in present study may be related to use of erythromycin in treatment of disease caused by $C$. difficile and common infections, increase exposure of this isolates to new macrolide, efflux of the drug and ribosomal methylation (42). Cross resistance between clindamycin and macrolides is well described by several investigators (42). In this study 30 isolates were simultaneously resistant to both clindamycin and erythromycin antibiotics. Cross resistance to clindamycin and erythromycin is most likely due to cross resistance with other macrolide, lincosamide antibiotics and the presence of erythromycin ribosomal methylase $\mathrm{B}$ (ermB) genes and also acquired resistance genes via a non-plasmid-mediated mechanism (22).

Other studies showed that percentage of $C$. difficile multidrug-resistant strains varies from one geographic region to another and ranges between $2.5 \%$ and $66 \%$ (24, 25). Our study showed that, $48 \%$ of isolates were MDR. According to study that was conducted by The European Study Group on Clostridium difficile (ESGCD) in 2008, $25.9 \%$ of isolates were resistance to at least three antibiotics (14).The frequency of MDR among isolates of C. difficile is increasing. The studies were performed by several investigators exhibited that resistance to erythromycin, clindamycin and moxifloxacin increased among C. difficile isolates (29). A high incidence of MDR strains was found in ICU and internal medicine wards in our study. It could be attributable to high usage of antimicrobials agents in ICU. Continued use of antibiotic for treatment of CDI should be supported by monitoring of antimicrobial susceptibility to prevent the spread of resistant isolates and also eliminate the need of antibiotics for a prolonged period (43).

In conclusion, this study has shown that resistance to metronidazole and vancomycin among our isolates was very low while full resistant to cephalosporines among our $C$. difficile isolates was common. Although resistant to metronidazole has seen among our isolates but it seems that metronidazole and vancomycin can be effective drugs for treatment of CDI. According to our findings, cefotaxim, clindamycin, erythromycin are not effective drugs for treatment of CDI. Progressive increase in resistant to cefotaxim, clindamycin, erythromycin and multiple resistances to antibiotics in present study, may be related to increased usage of these antibiotics for treatment of CDI and ability of strains in acquisition of resistance genes. Continuous Surveillance for $C$. difficile multidrug-resistant strains is necessary to prevent the further spread of resistant isolates. 


\section{Acknowledgements}

We appreciate the cooperation of the staff of Research Center for Gastroenterology and liver Diseases and Shahid Beheshti University of Medical Sciences.

\section{Authors' Contribution}

None declared.

\section{Financial disclosure}

None declared.

\section{Funding/Support}

This investigation was supported by a grant from Research Center for Gastroenterology and liver Diseases, Shahid Beheshti University of Medical Sciences.

\section{References}

1. Pépin Jacques, Valiquette Louis, Cossette Benoit. Mortality attributable to nosocomial Clostridium difficile-associated disease during an epidemic caused by a hypervirulent strain in Quebec. Can Med Assoc J. 2005;173(9):1037-1042.

2. Bartlett JG. Narrative review: the new epidemic of Clostridium difficile-associated enteric disease. Ann Intern Med. 2006;145(10):75864.

3. Voth DE, Ballard JD. Clostridium difficile toxins: mechanism of action and role in disease. Clin Microbiol Rev. 2005;18(2):247-63.

4. Owens RC, Jr, Donskey CJ, Gaynes RP, Loo VG, Muto CA. Antimicrobial-associated risk factors for Clostridium difficile infection. Clin Infect Dis. 2008;46 Suppl 1:S19-31.

5. Pituch H, Obuch-Woszczatynski P, Wultanska D, Nurzynska G, Harmanus C, Banaszkiewicz A, et al. Characterization and antimicrobial susceptibility of Clostridium difficile strains isolated from adult patients with diarrhoea hospitalized in two university hospitals in Poland, 2004-2006. J Med Microbiol. 2011;60(Pt 8):1200-5.

6. Shaughnessy MK, Amundson WH, Kuskowski MA, DeCarolis DD, Johnson JR, Drekonja DM. Unnecessary antimicrobial use in patients with current or recent Clostridium difficile infection. Infect Control Hosp Epidemiol. 2013;34(2):109-16.

7. Cocanour CS. Best strategies in recurrent or persistent Clostridium difficile infection. Surg Infect (Larchmt). 2011;12(3):235-9.

8. Dong D, Zhang L, Chen X, Jiang C, Yu B, Wang X, et al. Antimicrobial susceptibility and resistance mechanisms of clinical Clostridium difficile from a Chinese tertiary hospital. Int J Antimicrob Agents. 2013;41(1):80-4.

9. Kelly CP, LaMont JT. Clostridium difficile--more difficult than ever. N Engl J Med. 2008;359(18):1932-40.

10. Venuto C, Butler M, Ashley ED, Brown J. Alternative therapies for Clostridium difficile infections. Pharmacotherapy.2010;30(12):126678.

11. Gerding DN, Muto CA, Owens RC, Jr. Treatment of Clostridium difficile infection. Clin Infect Dis. 2008;46 Suppl 1:S32-42.

12. Pelaez T, Alonso R, Perez C, Alcala L, Cuevas O, Bouza E. In vitro activity of linezolid against Clostridium difficile. Antimicrob Agents Chemother. 2002;46(5):1617-8.

13. Pelaez T, Cercenado E, Alcala L, Marin M, Martin-Lopez A, MartinezAlarcon J, et al. Metronidazole resistance in Clostridium difficile is heterogeneous. J Clin Microbiol. 2008;46(9):3028-32.

14. Spigaglia P, Barbanti F, Mastrantonio P. Multidrug resistance in European Clostridium difficile clinical isolates. J Antimicrob Chemother. 2011;66(10):2227-34.

15. Fenner L, Frei R, Gregory M, Dangel M, Stranden A, Widmer AF Epidemiology of Clostridium difficile-associated disease at University Hospital Basel including molecular characterisation of the isolates 2006-2007. Eur JClin Microbiol Infect Dis. 2008;27(12):1201-7.
16. Riley TV, Brazier JS, Hassan H, Williams K, Phillips KD. Comparison of alcohol shock enrichment and selective enrichment for the isolation of Clostridium difficile. Epidemiol Infect. 1987;99(2):355-9.

17. Cohen SH, Tang YJ, Silva J, Jr. Analysis of the pathogenicity locus in Clostridium difficile strains. J Infect Dis. 2000;181(2):659-63.

18. Hecht DW. Methods for Antimicrobial Susceptibility Testing of Anaerobic Bacteria: Approved Standard. 2007.

19. Bartlett JG. Clostridium difficile-associated Enteric Disease. Curr Infect Dis Rep. 2002;4(6):477-483.

20. Hsu MS, Wang JT, Huang WK, Liu YC, Chang SC. Prevalence and clinical features of Clostridium difficile-associated diarrhea in a tertiary hospital in northern Taiwan. J Microbiol Immunol Infect. 2006;39(3):242-8

21. Hookman P, Barkin JS. Clostridium difficile associated infection diarrhea and colitis. World J Gastroenterol. 2009;15(13):1554-80.

22. Barbut F, Mastrantonio P, Delmee M, Brazier J, Kuijper E, Poxton I. Prospective study of Clostridium difficile infections in Europe with phenotypic and genotypic characterisation of the isolates. Clin Microbiol Infect. 2007;13(11):1048-57.

23. Martin H, Willey B, Low DE, Staempfli HR, McGeer A, Boerlin P, et al. Characterization of Clostridium difficile strains isolated from patients in Ontario, Canada, from 2004 to 2006. J Clin Microbiol. 2008;46(9):2999-3004.

24. Huang H, Fang H, Weintraub A, Nord CE. Distinct ribotypes and rates of antimicrobial drug resistance in Clostridium difficile from Shanghai and Stockholm. Clin Microbiol Infect. 2009;15(12):1170-3.

25. Kim H, Jeong SH, Roh KH, Hong SG, Kim JW, Shin MG, et al. Investigation of toxin gene diversity, molecular epidemiology, and antimicrobial resistance of Clostridium difficile isolated from 12 hospitals in South Korea. Korean J Lab Med. 2010;30(5):491-7.

26. Pelaez T, Alcala L, Alonso R, Rodriguez-Creixems M, Garcia-Lechuz JM, Bouza E. Reassessment of Clostridium difficile susceptibility to metronidazole and vancomycin. Antimicrob Agents Chemother. 2002;46(6):1647-50.

27. Bourgault AM, Lamothe F, Loo VG, Poirier L. In vitro susceptibility of Clostridium difficile clinical isolates from a multi-institutional outbreak in Southern Quebec, Canada. Antimicrob Agents Chemother. 2006;50(10):3473-5.

28. Aspevall O, Lundberg A, Burman LG, Akerlund T, Svenungsson B. Antimicrobial susceptibility pattern of Clostridium difficile and its relation to PCR ribotypes in a Swedish university hospital. Antimicrob Agents Chemother. 2006;50(5):1890-2.

29. Taori SK, Hall V, Poxton IR. Changes in antibiotic susceptibility and ribotypes in Clostridium difficile isolates from southern Scotland 1979-2004. JMed Microbiol. 2010;59(Pt 3):338-44

30. Brazier JS, Raybould R, Patel B, Duckworth G, Pearson A, Charlett A, et al. Distribution and antimicrobial susceptibility patterns of Clostridium difficile PCR ribotypes in English hospitals, 2007-08. Euro surveillance: bulletin europeen sur les maladies transmissibles= European communicable disease bulletin. 2008;13(41):541-544.

31. Lin YC, Huang YT, Tsai PJ, Lee TF, Lee NY, Liao CH, et al. Antimicrobial susceptibilities and molecular epidemiology of clinical isolates of Clostridium difficile in taiwan. Antimicrob Agents Chemother 2011;55(4):1701-5.

32. Wong SamsonSai-Yin, Woo PatrickChiu-Yat, Luk Wei-Kwang, Yuen Kwok-Yung. Susceptibility testing of Clostridium difficile against metronidazole and vancomycin by disk diffusion and Etest. Dign Micr Infec Dis. 1999;34(1):1-6.

33. Gardner E, Meghani N, Mancuso P, Thomson A. Recognizing metronidazole resistant C. difficile. Nurse Pract. 2011;36(11):8-11.

34. Wullt M, Odenholt I. A double-blind randomized controlled trial of fusidic acid and metronidazole for treatment of an initial episode of Clostridium difficile-associated diarrhoea. J Antimicrob Chemother. 2004;54(1):211-6.

35. Pelaez T, Alcala L, Alonso R, Martin-Lopez A, Garcia-Arias V, Marin $\mathrm{M}$, et al. In vitro activity of ramoplanin against Clostridium difficile, including strains with reduced susceptibility to vancomycin or with resistance to metronidazole. Antimicrob Agents Chemother. 2005;49(3):1157-9.

36. Hecht DW, Galang MA, Sambol SP, Osmolski JR, Johnson S, Gerding DN. In vitro activities of 15 antimicrobial agents against 110 toxi- 
genic clostridium difficile clinical isolates collected from 1983 to 2004. Antimicrob Agents Chemother. 2007;51(8):2716-9.

37. Jamal WafaaY, Mokaddas EimanM, Verghese TinaL, Rotimi VO. In vitro activity of 15 antimicrobial agents against clinical isolates of Clostridium difficile in Kuwait. Int J Antimicrob Agents. 2002;20(4):270-274

38. John R, Brazier JS. Antimicrobial susceptibility of polymerase chain reaction ribotypes of Clostridium difficile commonly isolated from symptomatic hospital patients in the UK.J Hosp Infect. 2005;61(1):11-4.

39. Tenover FC, Tickler IA, Persing DH. Antimicrobial-resistant strains of Clostridium difficile from North America. Antimicrob Agents Chemother.2012;56(6):2929-32.
40. Huang H, Weintraub A, Fang H, Wu S, Zhang Y, Nord CE. Antimicrobial susceptibility and heteroresistance in Chinese Clostridium difficile strains. Anaerobe. 2010;16(6):633-5.

41. Huang H, Weintraub A, Fang H, Nord CE. Antimicrobial resistance in Clostridium difficile. Int J Antimicrob Agents. 2009;34(6):516-22.

42. Huang H, Wu S, Wang M, Zhang Y, Fang H, Palmgren AC, et al. Clostridium difficile infections in a Shanghai hospital: antimicrobial resistance, toxin profiles and ribotypes. Int JAntimicrob Agents. 2009;33(4):339-42.

43. Lakhi N, Ahmad F, Woothipoom W. Clostridium Difficile Associated Diarrhoea and the Rela-tionship to Antibiotic Prescription Practices and Proton Pump Inhibitor Use in Elderly Wards. Iran Red Crescent Med J. 2009;():12-16. 